\title{
Characteristics and Driving Factors of Nitrogen-Use Efficiency in Chinese Greenhouse Tomato Cultivation
}

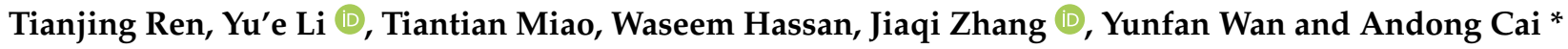

Citation: Ren, T.; Li, Y.; Miao, T.; Hassan, W.; Zhang, J.; Wan, Y.; Cai, A Characteristics and Driving Factors of Nitrogen-Use Efficiency in Chinese Greenhouse Tomato Cultivation. Sustainability 2022, 14, 805. https:// doi.org/10.3390/su14020805

Academic Editor: Mohammad Aslam Khan Khalil

Received: 29 November 2021 Accepted: 29 December 2021 Published: 12 January 2022

Publisher's Note: MDPI stays neutral with regard to jurisdictional claims in published maps and institutional affiliations.

Copyright: (C) 2022 by the authors. Licensee MDPI, Basel, Switzerland. This article is an open access article distributed under the terms and conditions of the Creative Commons Attribution (CC BY) license (https:// creativecommons.org/licenses/by/ $4.0 /)$.
Institute of Environment and Sustainable Development in Agriculture, Chinese Academy of Agricultural Sciences, Beijing 100081, China; rentianjing@outlook.com (T.R.); liyue@caas.cn (Y.L.); miao_miaotian@sina.com (T.M.); waseem.hassan@caas.cn (W.H.); zhangjiaqi@caas.cn (J.Z.); wanyunfan@caas.cn (Y.W.)

* Correspondence: caiandong@caas.cn; Tel./Fax: +86-10-8210-6022

\begin{abstract}
Excessive nitrogen fertilizer application in greenhouses could cause a significant variation in the nitrogen-use efficiency at the regional scale. This study aims to quantify agronomic nitrogenuse efficiency $\left(\mathrm{AE}_{\mathrm{N}}\right)$ and identify its driving factors across Chinese greenhouse tomato cultivation. Three hundred and forty-eight $\mathrm{AE}_{\mathrm{N}}$ values were obtained from 64 papers, including mineral nitrogen $(\mathrm{MN})$ and mineral combined with organic nitrogen $(\mathrm{MON})$ treatments. The average $\mathrm{AE}_{\mathrm{N}}$ values for the MN and MON treatments were $56.6 \pm 7.0 \mathrm{~kg} \mathrm{~kg}^{-1}$ and $34.6 \pm 3.5 \mathrm{~kg} \mathrm{~kg}^{-1}$, respectively. The $\mathrm{AE}_{\mathrm{N}}$ of the MN treatment was higher than that of the MON treatment for cultivation using soil with an organic matter content of less than $10 \mathrm{~g} \mathrm{~kg}^{-1}$ and the drip fertigation method. The $\mathrm{AE}_{\mathrm{Ns}}$ of the $\mathrm{MN}$ and MON treatments were divided into two segments according to the nitrogen application rate. The inflection points of the nitrogen application rate were 290 and $1100 \mathrm{~kg} \mathrm{~N} \mathrm{ha}^{-1}$ for the MN and MON treatments, respectively. When the ratio of organic nitrogen to total nitrogen was less than 0.4 , it was beneficial for improving the $\mathrm{AE}_{\mathrm{N}}$. The soil organic matter content and the nitrogen application rate were the most critical factors determining the $\mathrm{AE}_{\mathrm{N}}$. These results suggest that rationally reducing the nitrogen input and partially substituting mineral nitrogen with organic nitrogen can help improve the nitrogen-use efficiency.
\end{abstract}

Keywords: greenhouse tomato; management practices; soil properties; agronomic nitrogen-use efficiency

\section{Introduction}

The global demand for vegetable production is booming with the improvement of human living standards [1]. As the world's primary vegetable, the tomato is becoming increasingly popular because of its high concentration of vitamins, lycopene, minerals, antioxidants, and other nutrients [2,3]. Chinese tomato production is the largest globally, accounting for $33.82 \%$ of the global tomato production [4]. Tomato production in China increased from 50.7 million tons in 2013 to 61.6 million tons in 2018, and more than half of this tomato production came from greenhouse cultivation [4]. Nitrogen, as an essential nutrient, is vital for crops to grow, especially in greenhouse tomato cultivation. Aiming to obtain a high tomato yield, excessive mineral nitrogen fertilizer has been applied in greenhouse tomato production [5,6]. Based on the data of these papers published from 1965 to 2019, the average mineral nitrogen application rate was $656 \mathrm{~kg} \mathrm{~N} \mathrm{ha}^{-1}$, which was above the rate to meet the tomato demand and led to more reactive nitrogen loss, a higher environmental cost, and a lower nitrogen-use efficiency [7]. As a result, strictly controlling the overuse of mineral nitrogen fertilizer is essential to decrease environmental pollution and increase nitrogen utilization. At present, the Chinese Government has proposed an accurate nutrition management framework to achieve the goal of zero growth in fertilizer use [8]. This could guide farmers to replace mineral nitrogen fertilizer with an organic fertilizer in the farming system, especially for greenhouse vegetable production [9]. The application of organic fertilizers, such as animal manure and straw residue, could promote 
the nutrient recycling of agricultural resources, improve soil fertility, and increase vegetable yield [10]. China is the global largest greenhouse tomato producer, with a planting area of one million hectares, of which $42 \%$ is used for open-air cultivation and $35 \%$ is used for greenhouse cultivation, and abundant manure and straw resources [4]. Therefore, clarifying how to rationally manage nitrogen nutrition in greenhouses, including mineral and organic fertilizers, is crucial.

Mineral nitrogen, i.e., ammonium and nitrate nitrogen, can be easily absorbed by vegetables [11]. The application of mineral nitrogen usually results in a quicker reaction compared with organic nitrogen. Organic nitrogen is first degraded into mineral nitrogen, which can then be taken up by vegetables. When mineral nitrogen is combined or substituted with organic nitrogen, the corresponding yield and nitrogen-use efficiency remains uncertain. Inconsistent results have been reported based on field experiments. Compared with mineral nitrogen applied alone, the combined application of mineral nitrogen and organic nitrogen increased [12] or decreased [13] the nitrogen-use efficiency, or no significant differences [14] were observed. These variations could be attributed to different farming systems, climate conditions, irrigation, and fertilization practices. On the other hand, greenhouse tomato cultivation is semiclosed and is quite different to open-air cultivation. The atmospheric environment inside the greenhouse is relatively stable. Hence, the nitrogen-use efficiency in greenhouse cultivation mainly depends on the management practices (fertilizer types, nitrogen application rate, and top-dressing method) [15] and the soil properties (soil types, soil pH, soil total nitrogen content, and soil organic matter) [14]. At present, for greenhouse tomato cultivation, little is known about the responses and trends of the tomato yield and nitrogen-use efficiency under different management practices and soil properties at the regional scale. Moreover, changes in the ratio of organic nitrogen to total nitrogen can also affect the tomato yield and nitrogen-use efficiency. Previous studies have shown that a moderate substitution ratio of organic nitrogen to total nitrogen can increase the nitrogen-use efficiency without reducing the yield in wheat-summer maize rotation [16]. Still, a high ratio of organic nitrogen to total nitrogen can decrease the nitrogen-use efficiency and yield [17]. Whether there is a similar trend in greenhouse tomato cultivation needs further clarification.

China has taken into account the effects of the combined application of mineral and organic nitrogen in the sustainable production of greenhouse tomatoes. Currently, there have been several comprehensive reports on the effects of different nitrogen fertilizer forms on tomato production [18], tomato quality [19], and nitrous oxide emissions and nitrogen leaching [20]. However, the nitrogen-use efficiency of different nitrogen fertilizer forms has not been reported on at the regional scale. By reviewing and integrating the results of published articles based on greenhouse tomato cultivation, the overall objectives of this study are: (1) to comprehensively assess the effects of mineral nitrogen applied alone $(\mathrm{MN})$ and combined with organic nitrogen (MON) on nitrogen-use efficiency, and (2) to identify the driving factors determining nitrogen-use efficiency in the greenhouse tomato cultivation of China. The results of this study could fill the gaps in our knowledge about the responses of nitrogen application in greenhouses to the combined application of mineral and organic fertilizer at the national scale. It may serve as a guide for greenhouse tomato farmers to rationally manage mineral and organic nitrogen nutrition.

\section{Materials and Methods}

\subsection{Database Collection, Definitions, and Calculation}

To establish a comprehensive database of the application of different nitrogen forms across Chinese greenhouse tomato production, strict criteria (described below) were adopted to obtain the relevant experimental data from the literature published before and during March 2020 through Web of Science (http: / / apps.webofknowledge.com, accessed on 20 March 2020), Google Scholar (https: / / scholar.google.com, accessed on 20 March 2020), and China Knowledge Resource Integrated Database (http:/ / www.cnki.net/, 20 March 2020). Keywords included "China", "greenhouse", "tomato", "nitrogen”, and "yield”. The 
selected data needed to meet the following requirements: (a) the experiments were carried out under greenhouse conditions, and laboratory and pot experiments were excluded; (b) the experimental variety was ordinary tomato, excluding cherry tomato; (c) information about nitrogen application and tomato yield was reported; and (d) if the experimental data in the target literature were presented in the form of tables or text, we could directly obtain the experimental data. For figures, the software of GetData Graph Digitizer 2.24 was used to obtain these data indirectly.

Nitrogen fertilizer forms were divided into $\mathrm{MN}$ and MON to explore their effects on tomato production and nitrogen-use efficiency in the greenhouse. The substitution ratios of nitrogen application by organic fertilizer were calculated simultaneously. The nitrogen fertilizer application rate was converted into pure nitrogen. If pure nitrogen was shown in the literature, it was directly recorded in our database. If only the content was specified, the pure nitrogen amount was obtained by statistical calculation. If the nitrogen content of the organic fertilizer was not provided, the organic nitrogen content could be calculated according to "China Organic Fertilizer Nutrition" [21]. For organic nitrogen types, the most significant contributor came from the manure of poultry (51\%) and livestock (21\%), followed by commercial organic fertilizer (23\%), straw, and biogas residue (5\%).

Different management practices and soil properties were also extracted and clarified from the targeted literature, including fertilizer types (urea, slow controlled-release fertilizer, diammonium phosphate, water-soluble fertilizer), top-dressing methods (fertilization with flooding water, drip fertigation, furrow irrigation with fertilization), and soil physicochemical properties (soil types and texture, soil organic matter, soil total and available nitrogen, soil total and available phosphorus, and soil $\mathrm{pH}$ ). Complex natural environments, diverse climate types, and a high intensity of human activities lead to the uniqueness of Chinese soil. The main soil types in China can be summarized as red soil, brown soil, black soil, chestnut soil, desert soil, tidal soil, irrigation and silt soil, paddy soil, saline-alkaline soil, and so on. To be consistent with international soil classification, soil types in our study were divided into anthrosols (hortisols, rigosols, and paddy soil), arenosols, cambisols, gleysols, and solonchaks, according to the FAO classification [22]. Soil organic matter was divided into three categories: $<10 \mathrm{~g} \mathrm{~kg}^{-1}, 10-20 \mathrm{~g} \mathrm{~kg}^{-1}$, and $>20 \mathrm{~g} \mathrm{~kg}^{-1}$. Soil $\mathrm{pH}$ was divided into acidic soil $(<6.5)$, neutral soil (6.5-7.5), and alkaline soil (>7.5) (Tables S1 and S2).

Nitrogen agronomic efficiency (AEN) reflected the yield production per unit amount of nitrogen fertilizer and unit area. It was calculated via the following equation [18]:

$$
\mathrm{AE}_{\mathrm{N}}=\left(\mathrm{Y}-\mathrm{Y}_{0}\right) / \mathrm{F}
$$

where $\mathrm{Y}$ and $\mathrm{Y}_{0}\left(10^{3} \mathrm{~kg}^{-1}\right)$ are the tomato yields with nitrogen fertilization and without fertilization, respectively, and $\mathrm{F}\left(\mathrm{kg} \mathrm{ha}^{-1}\right)$ represents the total amount of nitrogen applied.

The relative output value was used to assess the relationship between yield earning and fertilizer cost. It was calculated via the following equation:

Output value $=($ tomato price $\times$ tomato yield $)-(\mathrm{N}$ fertilizer price $\times$ amount of $\mathrm{N}$ fertilizer $)$

The average price of tomatoes was $0.72 \mathrm{USD} \mathrm{kg}^{-1}$. The average prices of urea, slow controlled-release fertilizer, diammonium phosphate, water-soluble fertilizer, and organic fertilizer were $0.29,0.65,0.35,0.32,1.61$, and $0.10 \mathrm{USD} \mathrm{kg}^{-1}$, respectively. All prices were obtained from the Chinese food information network (http:/ / www.grain.gov.cn/ Grain/Wheat.aspx, 25 June 2020) and China's fertilizer network (http://www.fert.cn/, 25 June 2020).

In total, we collected 348 paired data entries from 64 published papers. The experimental sites spanned from $27.8^{\circ} \mathrm{N}$ (Ruian) to $45.8^{\circ} \mathrm{N}$ (Haerbin) in geographic latitude and from $98.7^{\circ} \mathrm{E}$ (Jiuquan) to $126.7^{\circ} \mathrm{E}$ (Haerbin) in geographic longitude (Figure 1). For MN, 41 studies were conducted with 200 paired data, and MON was included in 32 studies with 
148 paired data (Table S2). To ensure the accuracy of results, variables with a sample size of less than five were not shown in the figures or tables.

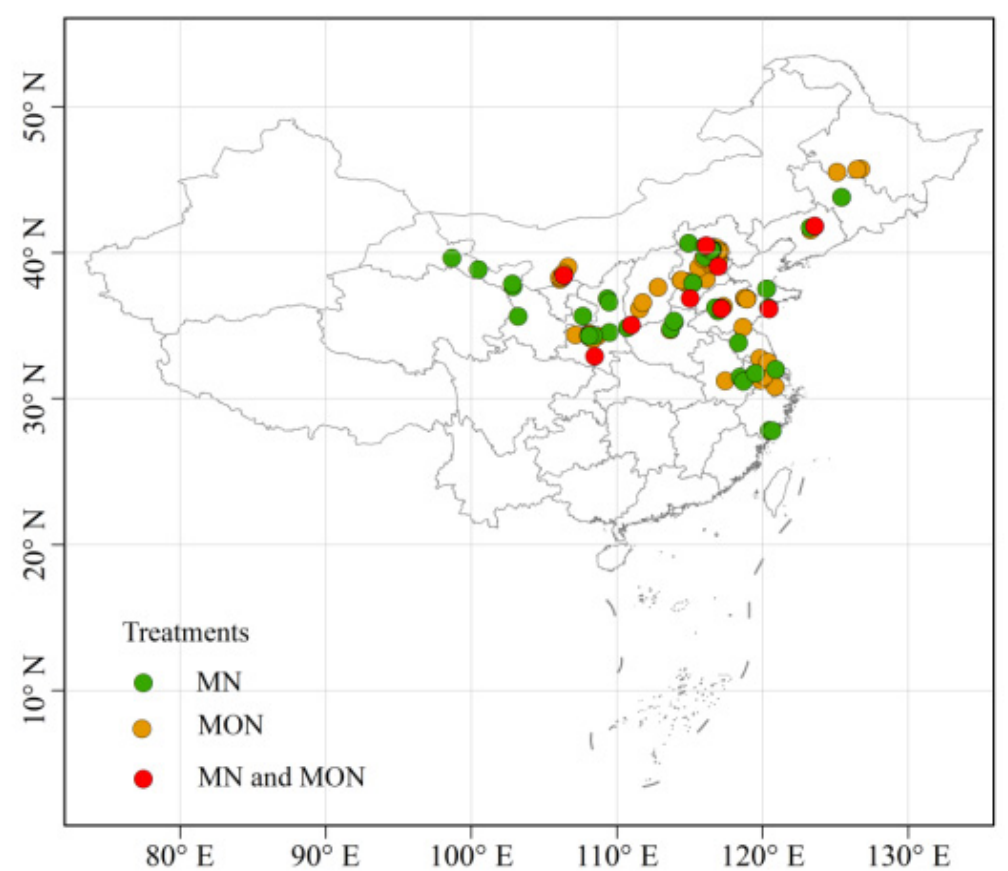

Figure 1. The distribution of 121 experimental sites from 64 published papers. Letters MN (50 experimental sites) and MON (41 experimental sites) represent mineral nitrogen applied alone and mineral combined with organic nitrogen, respectively.

\subsection{Statistical Analysis}

The distribution of 121 experimental sites is shown in Figure 1, using ArcMap10.5. A linear regression equation was used to fit the relationship between $\mathrm{AE}_{\mathrm{N}}$ and longitude under $\mathrm{MN}$ and $\mathrm{MON}$ treatments. The difference in $\mathrm{AE}_{\mathrm{N}}$ between $\mathrm{MN}$ and MON treatments under different management practices and soil properties was analyzed by one-way ANOVA. An LSD test and an independent sample $t$-test were conducted using SPSS 20.0. The relationships between $\mathrm{AE}_{\mathrm{N}}$ and output value and nitrogen fertilizer application rate were examined by the quadratic polynomial regression using SigmaPlot 10.0. To explore the relative influence of management practices and soil properties in controlling the variation of $\mathrm{AE}_{\mathrm{N}}$, based on theoretical knowledge and the validity of our dataset, a total of 11 variables (soil type and texture, soil organic matter, soil total and available nitrogen, soil total and available phosphorus, soil $\mathrm{pH}$, nitrogen application rate, fertilizer types, and top-dressing methods) were first input into a boosted regression tree model to select the driving factors. Six variables (nitrogen application rate, soil organic matter, top-dressing methods, soil $\mathrm{pH}$, soil types, and fertilizer types) were retained according to their effects on predictive performance. The boosted regression tree model adopted the recommended parameter values: learning rate (0.01), bag fraction (0.50), cross-validation (10), and tree complexity (5) $[23,24]$. The Bernoulli method was used for the boosted regression tree analysis because of the categorical variables $[23,24]$. The boosted regression tree model was constructed using the gbm package in R, version 3.3.3 [24].

\section{Results}

\subsection{Spatial Distribution}

The $\mathrm{AE}_{\mathrm{N}}$ under the $\mathrm{MN}$ and $\mathrm{MON}$ treatments showed a significant negative linear relationship with the longitude $(p<0.01)$ (Figure 2). The average $\mathrm{AE}_{\mathrm{N}}$ under the $\mathrm{MN}$ treatment was $56.6 \pm 7.0 \mathrm{~kg} \mathrm{~kg}^{-1}$, which was higher than for the MON treatment $\left(34.6 \pm 3.5 \mathrm{~kg} \mathrm{~kg}^{-1}\right)$ 
(Figure 3). The MON treatment decreased the $\mathrm{AE}_{\mathrm{N}}$ by $38.9 \%$ compared with the $\mathrm{MN}$ treatment.

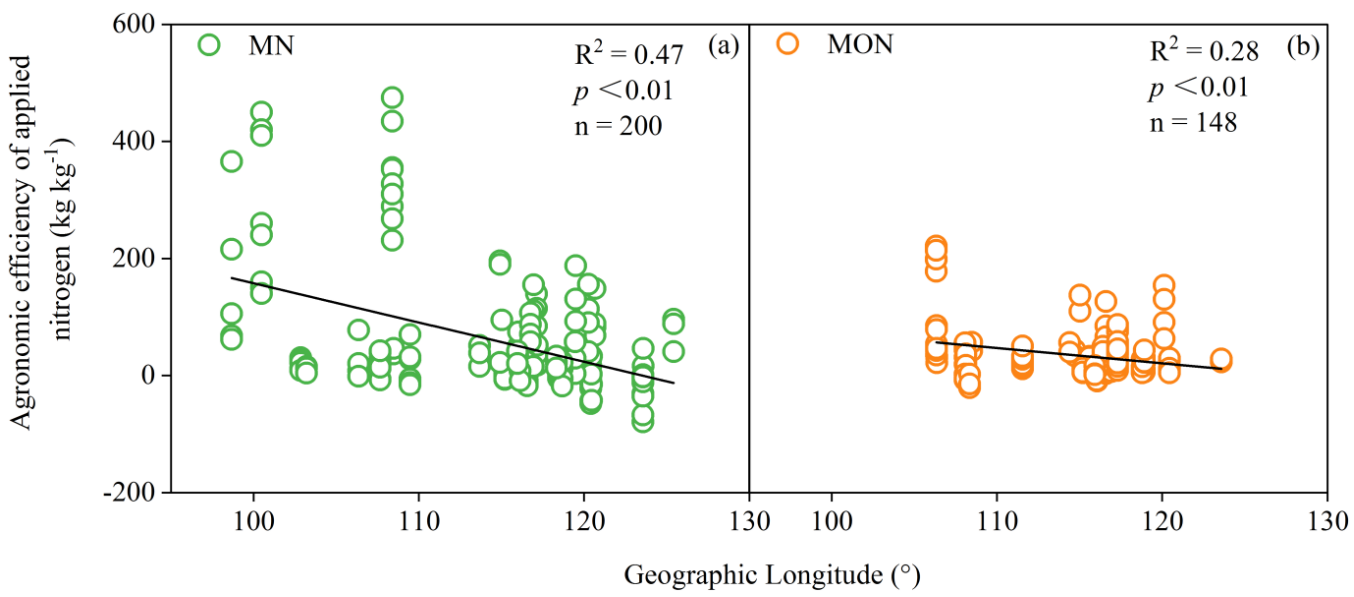

Figure 2. Geographic longitude patterns of agronomic efficiency of applied nitrogen $\left(\mathrm{kg} \mathrm{kg}^{-1}\right)$ when mineral nitrogen is applied alone (a) and when mineral combined with organic nitrogen (b) treatment is applied.
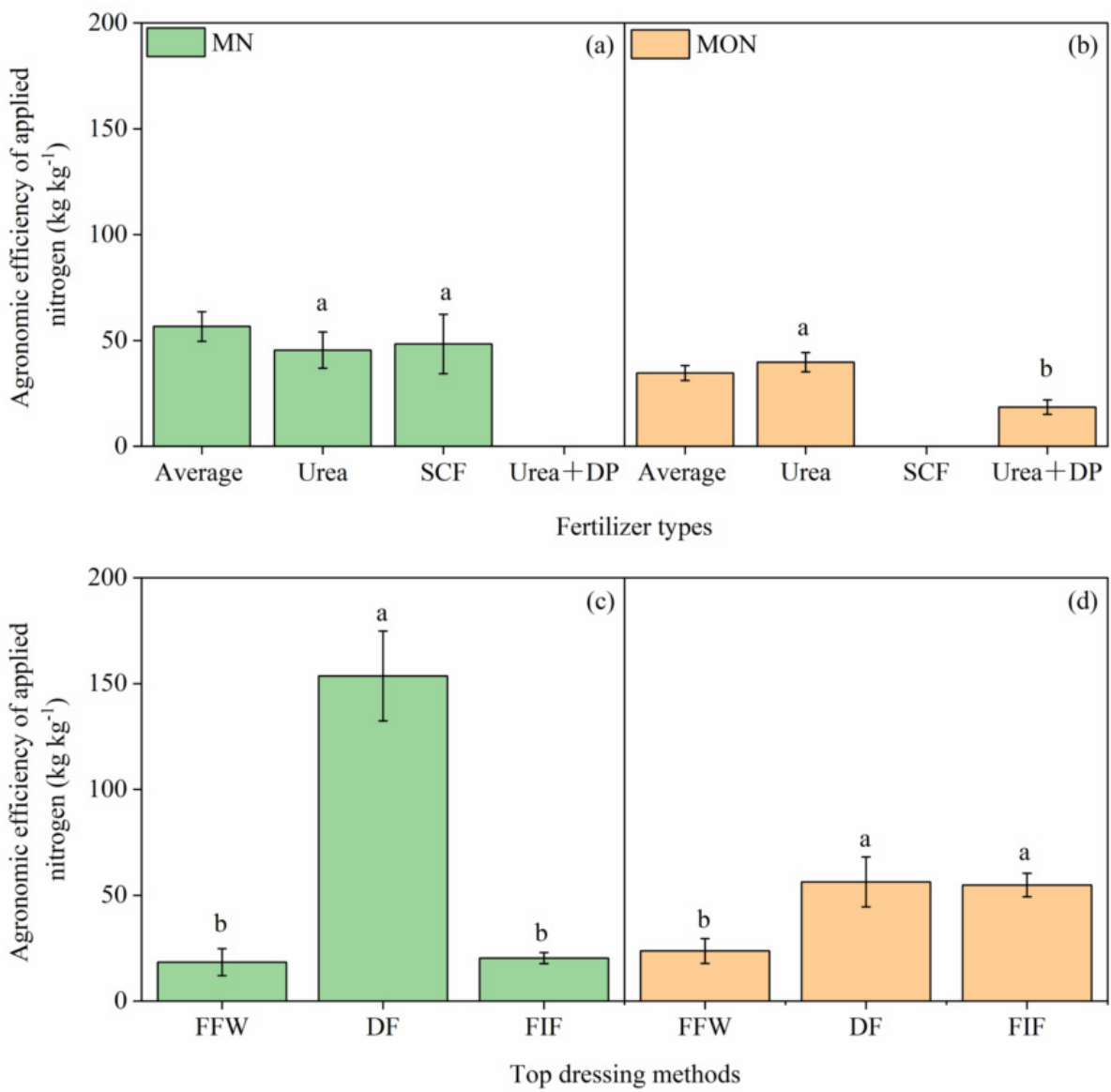

Figure 3. The agronomic efficiency of applied nitrogen $\left(\mathrm{kg} \mathrm{kg}^{-1}\right)$ when mineral nitrogen is applied alone $(\mathrm{MN})$ and when mineral combined with organic nitrogen (MON) is applied for fertilizer types $(\mathbf{a}, \mathbf{b})$ and top-dressing methods $(\mathbf{c}, \mathbf{d})$. Notes: fertilizer types included urea, slow controlled-release fertilizer (SCF), and diammonium phosphate (urea + DP); different top-dressing methods included fertilization with flooding water (FFW), drip fertigation (DF), and fertilization with furrow irrigation (FIF). Different letters denote significant differences at the $p<0.05$ level. 


\subsection{Management Practices}

For the fertilizer types, there was no significant difference between the urea and the slow controlled-release fertilizer for the $\mathrm{AE}_{\mathrm{N}}$ under the $\mathrm{MN}$ treatment, with 45.5 and $48.3 \mathrm{~kg} \mathrm{~kg}^{-1}$ (Figure $3 \mathrm{a}$ ), respectively. The $\mathrm{AE}_{\mathrm{N}}$ of the urea fertilizer used with the MON treatment $\left(39.8 \mathrm{~kg} \mathrm{~kg}^{-1}\right)$ was higher than that of the urea and diammonium phosphate fertilizer $\left(18.6 \mathrm{~kg} \mathrm{~kg}^{-1}\right.$ ) (Figure $3 \mathrm{~b}$ ). For the top-dressing methods, the $\mathrm{AE}_{\mathrm{N}}$ of drip fertigation used with the MN treatment $\left(153.6 \mathrm{~kg} \mathrm{~kg}^{-1}\right)$ was significantly higher than that of furrow irrigation with fertilization $\left(20.3 \mathrm{~kg} \mathrm{~kg}^{-1}\right)$ and fertilization with flooding water (18.4 kg kg-1) (Figure 3c). The $\mathrm{AE}_{\mathrm{Ns}}$ of drip fertigation and furrow irrigation with fertilization (56.3 and $54.9 \mathrm{~kg} \mathrm{~kg}^{-1}$, respectively) used alongside the MON treatment were higher than those of fertilization with flooding water $\left(23.7 \mathrm{~kg} \mathrm{~kg}^{-1}\right.$ ) (Figure 3d).

The $\mathrm{AE}_{\mathrm{Ns}}$ of the $\mathrm{MN}$ and $\mathrm{MON}$ treatments were divided into two segments according to the nitrogen application rates (Figure 4). The inflection points of the nitrogen application rate were 290 and $1100 \mathrm{~kg} \mathrm{ha}^{-1}$ for the MN and MON treatments, respectively. Before the inflection points, the $\mathrm{AE}_{\mathrm{Ns}}$ of the $\mathrm{MN}$ and $\mathrm{MON}$ treatments decreased rapidly, with slopes of 675.03 and 30.16, respectively. After the inflection points, the $\mathrm{AE}_{\mathrm{Ns}}$ of the $\mathrm{MN}$ and MON treatments showed a slight decrease, with slopes of 18.79 and 2.35, respectively. The output values were also divided into two segments that exhibited negative trends. The maximum output values under the MN and MON treatments were $0.75 \times 10^{5}$ and $0.79 \times 10^{5}$ USD ha $^{-1}$, respectively. The MON treatment increased the nitrogen input by $85.9 \%$ in the greenhouse tomatoes. A high ratio of organic nitrogen to total nitrogen resulted in a low $\mathrm{AE}_{\mathrm{N}}$. When the percentage of organic nitrogen to total nitrogen was less than 40, it was beneficial for improving the $\mathrm{AE}_{\mathrm{N}}$ (Figure 5).

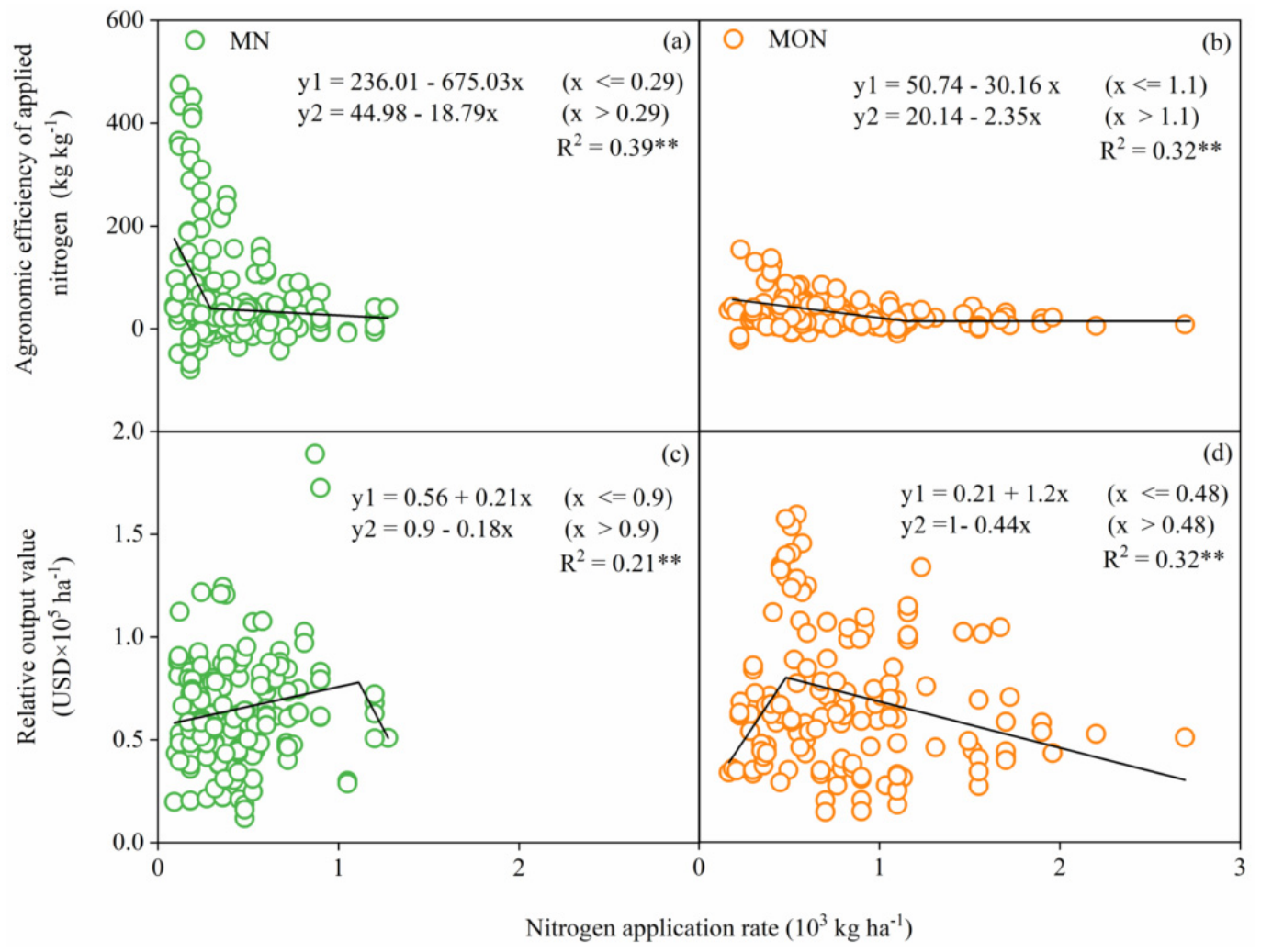

Figure 4. The relationship between nitrogen application rate $\left(10^{3} \mathrm{~kg} \mathrm{ha}^{-1}\right)$ and agronomic efficiency of applied nitrogen $\left(\mathrm{kg} \mathrm{kg}^{-1}\right)$ and relative output value $\left(\mathrm{USD} \times 10^{5} \mathrm{ha}^{-1}\right)$ under mineral nitrogen treatment $(\mathbf{a}, \mathbf{c})$ and mineral combined with organic nitrogen treatment $(\mathbf{b}, \mathbf{d}){ }^{* *}$ means significant correlation at the $p<0.01$ level. 


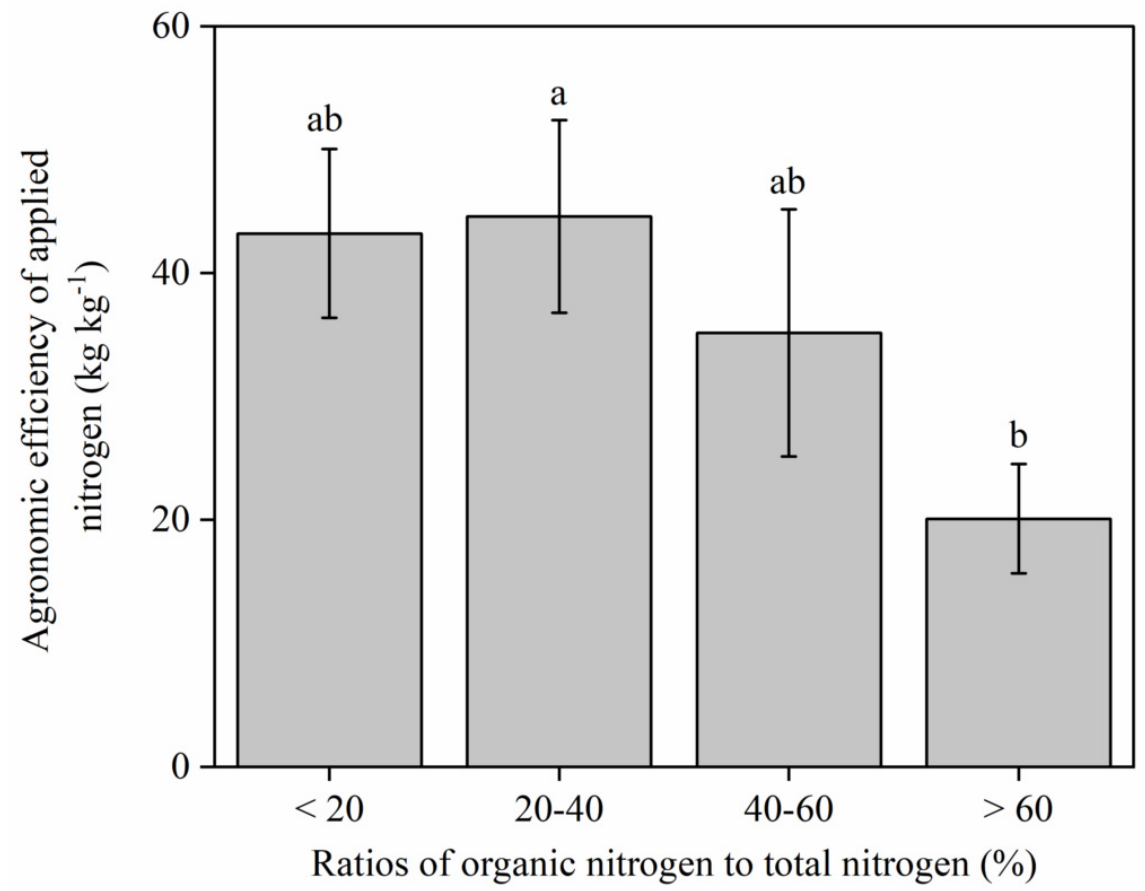

Figure 5. The effect of different ratios of organic nitrogen to total nitrogen (\%) on agronomic efficiency of applied nitrogen $\left(\mathrm{kg} \mathrm{kg}^{-1}\right)$. Different letters denote significant differences at the $p<0.05$ level.

\subsection{Soil Properties}

For the soil types, the $\mathrm{AE}_{\mathrm{N}}$ in the arenosols $\left(153.3 \mathrm{~kg} \mathrm{~kg}^{-1}\right)$ and solonchaks $\left(153.3 \mathrm{~kg} \mathrm{~kg}^{-1}\right)$ under the MN treatment was significantly higher than in the anthrosols, cambisols, and gleysols $\left(67.5,21.1\right.$, and $33.0 \mathrm{~kg} \mathrm{~kg}^{-1}$, Figure $\left.6 \mathrm{a}\right)$. Higher $\mathrm{AE}_{\mathrm{Ns}}$ under the MON treatment were found in the anthrosols $\left(46.5 \mathrm{~kg} \mathrm{~kg}^{-1}\right)$ and gleysols $\left(40.2 \mathrm{~kg} \mathrm{~kg}^{-1}\right)$ compared with the cambisols (Figure $6 \mathrm{~b}$ ). For the $\mathrm{MN}$ treatment, the $\mathrm{AE}_{\mathrm{N}}$ in soils with low levels of organic matter $\left(<10 \mathrm{~g} \mathrm{~kg}^{-1}\right)$ was significantly higher than in soils with high levels of organic matter $\left(>10 \mathrm{~g} \mathrm{~kg}^{-1}\right)$. The $\mathrm{AE}_{\mathrm{N}}$ under the $\mathrm{MN}$ treatment showed an increasing trend with the soil $\mathrm{pH}$. The $\mathrm{AE}_{\mathrm{N}}$ under the $\mathrm{MON}$ treatment showed no significant difference according to the different levels of organic matter content in the soil, the soil $\mathrm{pH}$, and the soil total nitrogen content (Figure $6 \mathrm{~b}, \mathrm{f}, \mathrm{h}$ ).

\subsection{Driving Factors}

The $\mathrm{AE}_{\mathrm{N}}$ under the $\mathrm{MN}$ and $\mathrm{MON}$ treatments was driven by the management practices and soil properties (Figure 7). The level of organic matter in the soil, nitrogen application rate, top-dressing methods, soil $\mathrm{pH}$, soil types, and fertilizer types accounted for $50.3 \%$, $22.4 \%, 13.1 \%, 8.8 \%, 3.5 \%$, and $1.9 \%$ of the $\mathrm{AE}_{\mathrm{N}}$ variations under the $\mathrm{MN}$ treatment, respectively, and for $34.7 \%, 29.4 \%, 17.8 \%, 10.9 \%, 4 \%$, and $3.2 \%$ of the $\mathrm{AE}_{\mathrm{N}}$ variations under the MON treatment, respectively. The levels of organic matter in the soil and the nitrogen application rate were the most influential variables on the $\mathrm{AE}_{\mathrm{N}}$ among the six selected variables. Overall, the boosted regression tree model could explain $92 \%$ and $86 \%$ of the $\mathrm{AE}_{\mathrm{N}}$ variance under the $\mathrm{MN}$ and $\mathrm{MON}$ treatments, respectively. 

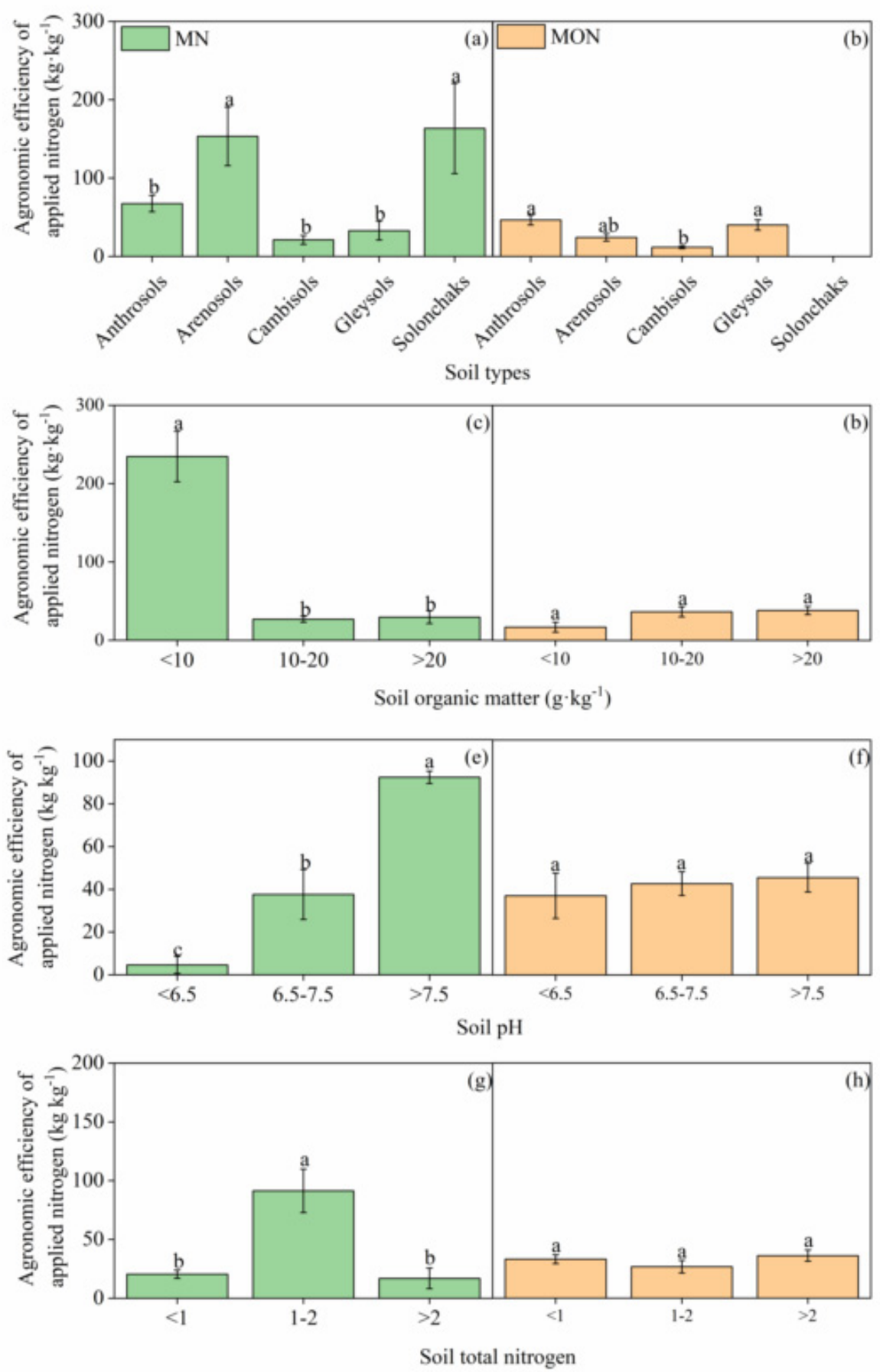

Figure 6. The agronomic efficiency of applied nitrogen $\left(\mathrm{kg} \mathrm{kg}^{-1}\right)$ under mineral nitrogen treatment $(\mathrm{MN})$ and mineral combined with organic nitrogen treatment (MON) for different soil types $(\mathbf{a}, \mathbf{b})$, levels of organic matter in the soil $\left(\mathrm{g} \mathrm{kg}^{-1} ;(\mathbf{c}, \mathbf{d})\right)$, soil $\mathrm{pH}(\mathbf{e}, \mathbf{f})$, and soil total nitrogen $\left(\mathrm{g} \mathrm{kg}^{-1} ;(\mathbf{g}, \mathbf{h})\right)$. Note: different letters denote significant differences at the $p<0.05$ level. 


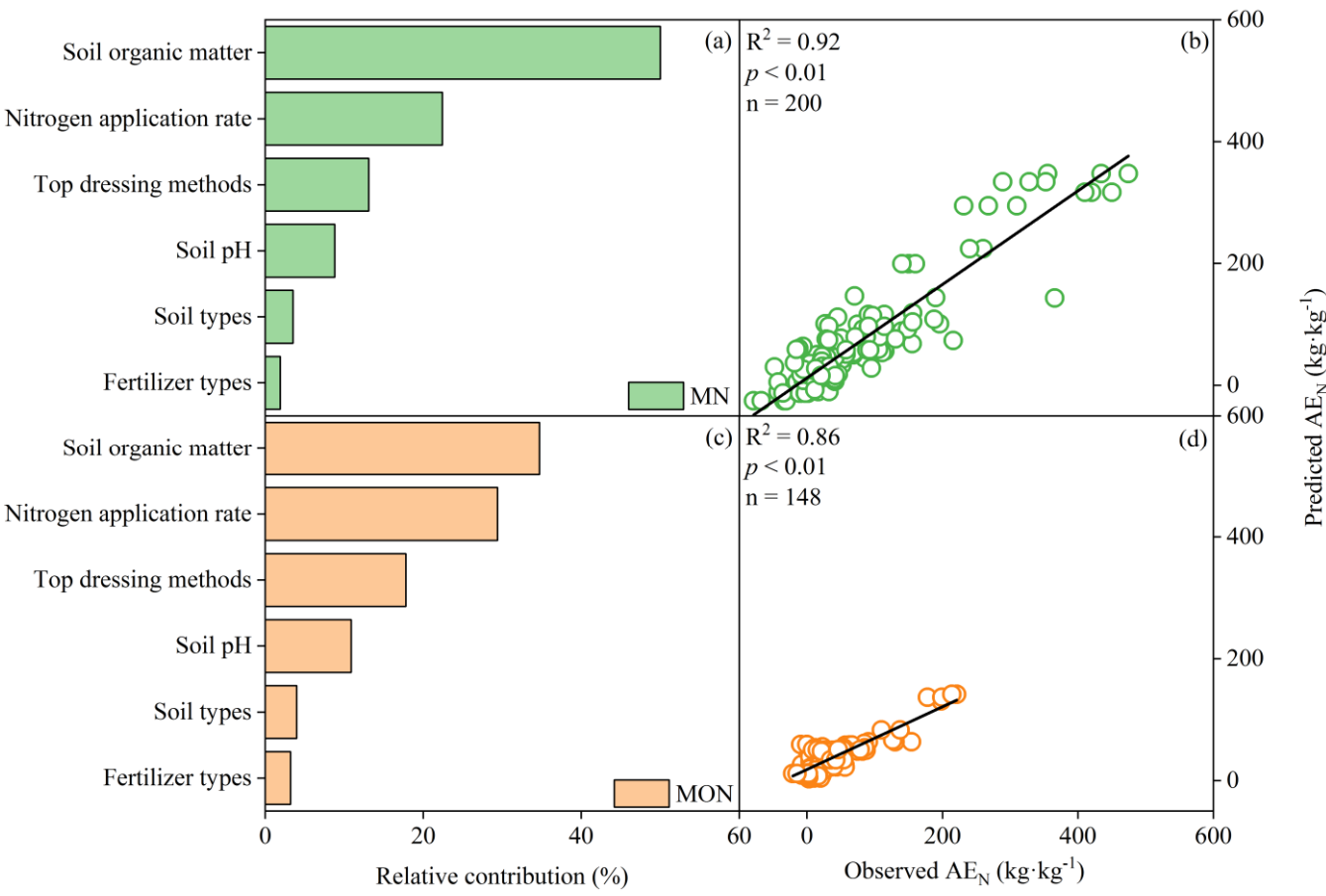

Figure 7. The relative influence (\%) of predictor variables for the boosted regression tree model of agronomic efficiency of applied nitrogen $\left(\mathrm{AE}_{\mathrm{N}}, \mathrm{kg} \mathrm{kg}^{-1}\right)$ under mineral nitrogen treatment (a) and mineral combined with organic nitrogen treatment (c). The observed agronomic efficiency of applied nitrogen $\left(\mathrm{kg} \mathrm{kg}^{-1}\right)$ and those predicted by the boosted regression tree model using various predictors are shown in $(\mathbf{b}, \mathbf{d})$. Note: predictor variables included management measures (nitrogen application rate, top-dressing methods, and fertilizer types) and soil properties (levels of organic matter in the soil, soil $\mathrm{pH}$, and soil types).

\section{Discussion}

In recent years, a large quantity of mineral nitrogen fertilizer has been used in greenhouse vegetable cultivation in China, which has contributed to yield improvement [5]. However, it has also caused high losses of reactive nitrogen from the environment, which has increased the risk of soil degradation and pollution [25]. The application of organic fertilization for vegetables is a time-honored practice and widely accepted by farmers in China. Previous studies have indicated that the combined application of mineral and organic fertilizer could improve the soil's physical, mineral, and biological properties and have benefits for the vegetable yield and quality improvement [26]. Our integrated analysis showed that the MON treatment increased the yield by $16.2 \%$ but decreased the $\mathrm{AE}_{\mathrm{N}}$ by $38.9 \%$ compared with the MN treatment (Figure S1). From the results of the global meta-analysis, the nitrogen-use efficiency of mineral nitrogen fertilizer applied alone in greenhouse vegetables was $61.1 \%$ higher than that of mineral combined with organic nitrogen fertilizer [27]. Moreover, the $\mathrm{AE}_{\mathrm{N}}$ gradually reduced with the ratio of organic nitrogen to total nitrogen from $20 \%$ to above $60 \%$. Vegetables cannot directly use organic nitrogen unless microorganism decomposition occurs, that is, mineralization [28]. Correspondingly, unlike the quicker reactions of nitrogen from mineral fertilizer, organic nitrogen may present a hysteretic supply of the available nitrogen and result in a lower nitrogen-use efficiency [13]. For the MN and MON treatments, the average nitrogen application rates were $434 \mathrm{~kg} \mathrm{ha}^{-1}$ and $807 \mathrm{~kg} \mathrm{ha}^{-1}$, respectively (Figure S1). Thus, a high nitrogen input could cause a low $\mathrm{AE}_{\mathrm{N}}$, especially for the MON treatment.

A recent meta-analysis indicated that the partial substitution of mineral nitrogen for organic nitrogen increased upland crop yield and nitrogen-use efficiency, which was not inconsistent with our results regarding greenhouse tomato production [29]. The nitrogen demand for upland crops is smaller than for vegetables in the greenhouse. Organic fertil- 
izers provide the slow release of nitrogen by mineralization as an additional source and improve soil structure and microorganism activity, which benefits crop growth, especially at reproductive stages [30]. For tomatoes in greenhouses, the biomass is much larger than for most crops. Thus, the demand for nitrogen is immense at the vegetative stage. Organic fertilizer may not provide sufficient nitrogen for the initial stage of tomatoes because of its slow-release effect. Hence, a high ratio of organic nitrogen to total nitrogen caused a low $\mathrm{AE}_{\mathrm{N}}$ in our study. The complete substitution of mineral nitrogen for organic nitrogen significantly decreased the crop nitrogen-use efficiency by $20.5 \%$ [31]. Xia also showed that the crop yield and nitrogen-use efficiency would decrease when the ratio of organic nitrogen to total nitrogen was above $75 \%$ [32]. The substitution of $25 \%$ of the recommended fertilizer dose was possible when a higher amount of organic manure and biofertilizer were combined together in tomato cultivation in India [33]. All these results suggest that when the ratio of organic nitrogen to total nitrogen is much higher than $50 \%$, the hysteretic supply of nitrogen affects plants' nitrogen-use efficiency and yield output. Hence, although organic fertilizer has many advantages in improving soil fertility, it is important to balance the ratio of mineral nitrogen to organic nitrogen reasonably to provide enough nutrition, thus increasing the nitrogen-use efficiency. Based on the results of our study, a high percentage of organic nitrogen to total nitrogen is not recommended in greenhouse tomato cultivation.

Understanding the driving factors controlling nitrogen-use efficiency is necessary for developing effective fertilizer strategies in greenhouse tomato cultivation. Our boosted regression tree analysis results showed that organic matter content of the soil was the most influential variable determining the $\mathrm{AE}_{\mathrm{N}}$, accounting for $50.3 \%$ and $34.7 \%$ of the variation under the MN and MON treatments, respectively. The organic matter content of the soil plays a vital role in maintaining soil fertility and improving soil structure, and thus helps to increase nitrogen-use efficiency [34]. A study into the conservation agriculture and integrated soil fertility management of Kenya showed that the low-fertility fields had a significantly lower agronomic use efficiency compared to the high-fertility fields [35]. As the combined application of organic fertilizer could replenish organic matter in soil, the relative influence of organic matter was lower in the MON treatment than in the MN treatment. On the other hand, the spatial variability of the $\mathrm{AE}_{\mathrm{N}}$ indicated that the nitrogen-use efficiency decreased with an increased longitude in China. This could be attributed to the low organic matter content of the soil and the poor soil quality. With an increased longitude, the climate becomes dry. The soil water content also decreases in West China, limiting plant nitrogen uptake [36]. Additionally, soil organic matter enhances the immobilization of external nitrogen by soil microorganisms and clay minerals, consequently reducing leaching loss and improving nitrogen-use efficiency [37]. It is suggested that the application of organic fertilizer should be increased when soil organic matter content is limited, especially in West China.

The nitrogen application rate was another critical factor affecting tomato nitrogenuse efficiency. The $\mathrm{AE}_{\mathrm{N}}$ of the MON treatment decreased slowly and smoothly with the nitrogen application rate, while the $\mathrm{AE}_{\mathrm{N}}$ of the $\mathrm{MN}$ treatment decreased sharply. This might be due to the slow release of nitrogen from organic fertilizer [28]. Excessive nitrogen application was found in 52 studies (accounting for $14.9 \%$ of all studies), giving negative values of $\mathrm{AE}_{\mathrm{N}}$. In these cases, the available nitrogen in the soil was rich and sufficient for tomato growth due to the abundant residual nitrogen from preceding vegetable cultivation. Further application of nitrogen fertilizer had little benefit to yield improvement. According to research conducted in Florida, tomato production systems showed that increasing the rate of nitrogen fertilizer did not result in benefits to fruit and/or shoot biomass nor to $\mathrm{N}$ accumulation, but substantially increased $\mathrm{NO}_{3}-\mathrm{N}$ leaching [38]. Even worse, excessive nitrogen might cause nutrient stress, thus inhibiting plant growth and leading to a series of environmental pollutions [39]. The relative output value increased and reached a peak value when more nitrogen was applied. Rationally determining the nitrogen rate should balance the nitrogen-use efficiency, cost, and benefits. The fitted curves of the $\mathrm{AE}_{\mathrm{N}}$ and the relative output value in our study suggested that: (1) nitrogen application was sufficient in 
Chinese greenhouse tomato cultivation, and the tremendous nitrogen application rate was the main reason behind the low nitrogen-use efficiency, especially for mineral combined with organic nitrogen fertilizer; and (2) excessive nitrogen could not achieve high output values because of the high input, and the inflection point might be used as a reference for designing a nitrogen application rate guideline.

Different top-dressing methods significantly affected the nitrogen-use efficiency by changing the synergistic role of water and fertilizer in crop growth [40]. Traditional fertilization with flooding water reduced the soil temperature and increased the air humidity in greenhouses, increasing the risk of low water- and nitrogen-use efficiency [41]. This was the reason for the low $\mathrm{AE}_{\mathrm{N}}$ of the top-dressing method of fertilization with flooding water for both the $\mathrm{MN}$ and MON treatments. Top-dressing with furrow irrigation showed a higher $\mathrm{AE}_{\mathrm{N}}$ and saved water compared with flooding irrigation. However, furrow irrigation and flooding irrigation could cause a considerable nitrogen loss by leaching, as nitrogen nutrients ran off along with the water flow [42]. Sánchez-Martín also reported that drip irrigation is a method that can be used to save water and mitigate the emission of the atmospheric pollutants $\mathrm{NO}$ and $\mathrm{N}_{2} \mathrm{O}$ in Spanish horticultural crops [43]. Drip fertigation is an advanced top-dressing method that could significantly reduce the input of nitrogen fertilizer and water in greenhouse cultivation [44] and presented the highest $\mathrm{AE}_{\mathrm{N}}$ in our study. Drip irrigation precisely controls the quantity and timing of fertilizer and irrigation application to positively influence soil microorganisms and root activity, thus promoting nitrogen- and water-use efficiency.

Other factors, such as the soil $\mathrm{pH}$, soil types, and fertilizer types, also impacted the nitrogen-use efficiency. A decrease in the soil $\mathrm{pH}$ leads to soil acidification, reduces soil microorganism and enzyme activity, and affects the vegetable rhizosphere, decreasing the $\mathrm{AE}_{\mathrm{N}}$ by controlling nitrogen absorption [45]. Additionally, the $\mathrm{AE}_{\mathrm{N}}$ under the $\mathrm{MN}$ treatment was lower compared with the MON treatment in soil with a $\mathrm{pH}<6.5$. Organic fertilizer application improved the soil buffering capacity and maintained a stable soil $\mathrm{pH}$ [46]. This was why there were no significant differences in the $\mathrm{AE}_{\mathrm{N}}$ under the $\mathrm{MON}$ treatment between acidic soil, neutral soil, and alkaline soil. Vegetables can directly absorb and utilize the fast-reacting nitrogen from mineral fertilizer in most soils. The anthrosol soil type enhances the retention of organic matter in soil due to its high clay content, which becomes a primary source of the nutrients released under conditions of insufficient organic matter during cultivation [47]. Therefore, the $\mathrm{AE}_{\mathrm{N}}$ under the $\mathrm{MN}$ treatment was higher than under the MON for different soil types. Controlled-release fertilizer can meet plants' nitrogen requirements according to their growth characteristics and cause lower nitrogen losses and environmental costs [48]. However, the price of controlled-release fertilizer is relatively high, which is a significant challenge for popularizing its use in Chinese greenhouses. A key issue is that the risk of profit loss must be small and, in many cases, that the profit increase must be substantial to make the technology attractive for a farmer.

\section{Conclusions}

This timely study identified the importance of field practices and soil properties in improving nitrogen-use efficiency. It can provide references and suggestions for managing mineral and organic nitrogen rationally in greenhouse tomatoes. The mineral nitrogen rate should be reduced, and the reduction percent can be judged according to the conditions of the residual nutrients in the soils of the greenhouse. Organic nitrogen can be used as a substitute for the decreased amount of mineral nitrogen. Especially for the low-carboncontent soil in West China, increasing the rate and ratio of organic fertilizer is recommended. Moreover, drip fertigation and controlled-release fertilization are considerably beneficial practices when integrated with decreased nitrogen input, further improving tomato yield and nitrogen-use efficiency in greenhouses. Our results emphasize that reasonable measures can be taken to reduce nitrogen input, increase nitrogen-use efficiency, and improve farmers' income according to the specific situation. 


\begin{abstract}
Supplementary Materials: The following supporting information can be downloaded at https: / / www.mdpi.com/article/10.3390/su14020805/s1, Table S1: summary of site characteristics, soil $\mathrm{pH}$, and soil organic matter $\left(\mathrm{g} \mathrm{kg}^{-1}\right)$ under mineral nitrogen applied alone and mineral combined with organic nitrogen treatments across Chinese greenhouse tomato cultivation; Table S2: the value of nitrogen agronomic use efficiency $\left(\mathrm{kg} \mathrm{kg}^{-1}\right)$ under different management practices and soil properties and the summary of nitrogen application rate $\left(\mathrm{kg} \mathrm{ha}^{-1}\right)$, tomato yield $\left(\mathrm{t} \mathrm{ha}^{-1}\right)$, output value (USD ha-1) for mineral nitrogen applied alone and mineral combined with organic nitrogen treatments. Notes: fertilizer types included urea, slowly controlled release fertilizer (SCF), and diammonium phosphate (Urea+DP); different top dressing methods included fertilization with flooding water (FFW), drip fertigation (DF) and fertilization with furrow irrigation (FIF); Figure S1: the yield $\left(\mathrm{Mg} \mathrm{ha}^{-1}, \mathrm{a}\right)$ and nitrogen application rate $\left(\mathrm{kg} \mathrm{kg}^{-1}, \mathrm{~b}\right)$ under mineral nitrogen applied alone $(\mathrm{MN})$ and mineral combined with organic nitrogen (MON).
\end{abstract}

Author Contributions: Conceptualization, T.R., Y.L. and A.C.; Data curation, T.R., T.M. and J.Z.; Investigation, Y.L., W.H. and Y.W.; Methodology, T.R. and A.C.; Resources, Y.L.; Supervision, Y.L.; Writing-original draft, T.R. and A.C. All authors have read and agreed to the published version of the manuscript.

Funding: This research was funded by National Natural Science Foundation of China (42007073), Chinese State Key Special Program on Severe Air Pollution Mitigation (Grant No. DQGG0208) and the National Key Research and Development Program (Grant No. 2018YFC0213300). We thank the authors whose data and work was included in our dataset.

Institutional Review Board Statement: Not applicable.

Informed Consent Statement: Not applicable.

Data Availability Statement: The data presented in this study are available on request from the corresponding author.

Conflicts of Interest: The authors declare no conflict of interest.

\title{
References
}

1. Brunetti, G.; Traversa, A.; De Mastro, F.; Cocozza, C. Short term effects of synergistic inorganic and organic fertilization on soil properties and yield and quality of plum tomato. Sci. Hortic. 2019, 252, 342-347. [CrossRef]

2. Kuscu, H.; Turhan, A.; Ozmen, N.; Aydinol, P.; Demir, A.O. Optimizing levels of water and nitrogen applied through drip irrigation for yield, quality, and water productivity of processing tomato (Lycopersicon esculentum Mill.). Hortic. Environ. Biotechnol. 2014, 55, 103-114. [CrossRef]

3. Maham, S.G.; Rahimi, A.; Subramanian, S.; Smith, D.L. The environmental impacts of organic greenhouse tomato production based on the nitrogen-fixing plant (Azolla). J. Clean. Prod. 2020, 245, 118679. [CrossRef]

4. FAO. Food and Agriculture Data. Available online: https://www.fao.org/faostat/zh/\#home (accessed on 27 May 2021).

5. Liang, L.; Ridoutt, B.G.; Lal, R.; Wang, D.; Wu, W.; Peng, P.; Hang, S.; Wang, L.; Zhao, G. Nitrogen footprint and nitrogen use efficiency of greenhouse tomato production in North China. J. Clean. Prod. 2019, 208, 285-296. [CrossRef]

6. Ti, C.; Luo, Y.; Yan, X. Characteristics of nitrogen balance in open-air and greenhouse vegetable cropping systems of China. Environ. Sci. Pollut. Res. Int. 2015, 22, 508-518. [CrossRef]

7. Qin, X.; Li, Y.; Wang, B.; Wan, Y.; Gao, Q.; Chen, X.; Chen, H.; Song, C. Nonlinear dependency of $\mathrm{N}_{2} \mathrm{O}$ emissions on nitrogen input in dry farming systems may facilitate green development in China. Agric. Ecosyst. Environ. 2021, 317, 107456. [CrossRef]

8. Ministry of Agriculture and Rural Affairs. People's Republic of China. Action Plan for Zero Growth of Chemical Fertilizer Use by 2020. 2015. Available online: http:/ /Www.Moa.Gov.Cn/Ztzl/Mywrfz/Gzgh/201509/T20150914_4827907.Htm (accessed on 27 May 2021).

9. Ministry of Agriculture and Rural Affairs. People's Republic of China. Technical Guidelines for Green Agricultural Development in China. 2018. Available online: http://Www.Moa.Gov.Cn/Gk/Ghjh_1/201807/T20180706_6153629.Htm (accessed on 27 May 2021).

10. Kalbani, F.O.S.A.; Salem, M.A.; Cheruth, A.J.; Kurup, S.S.; Senthilkumar, A. Effect of some organic fertilizers on growth, yield and quality of tomato (Solanum lycopersicum). Int. Lett. Nat. Sci. 2016, 53, 56-67. [CrossRef]

11. Mulvaney, R. Nitrogen-Inorganic forms. Methods Soil Anal. Part 3 Chem. Methods 1996, 5, 1123-1184.

12. Pan, G.; Zhou, P.; Li, Z.; Smith, P.; Li, L.; Qiu, D.; Zhang, X.; Xu, X.; Shen, S.; Chen, X. Combined inorganic/organic fertilization enhances $\mathrm{N}$ efficiency and increases rice productivity through organic carbon accumulation in a rice paddy from the Tai Lake region, China. Agric. Ecosyst. Environ. 2009, 131, 274-280. [CrossRef]

13. Heeb, A.; Lundegårdh, B.; Savage, G.; Ericsson, T. Impact of organic and inorganic fertilizers on yield, taste, and nutritional quality of tomatoes. J. Plant Nutr. Soil Sci. 2006, 169, 535-541. [CrossRef] 
14. Musyoka, M.W.; Adamtey, N.; Muriuki, A.W.; Cadisch, G. Effect of organic and conventional farming systems on nitrogen use efficiency of potato, maize and vegetables in the Central highlands of Kenya. Eur. J. Agron. 2017, 86, 24-36. [CrossRef]

15. Hartmann, T.E.; Yue, S.; Schulz, R.; He, X.; Chen, X.; Zhang, F.; Müller, T. Yield and N use efficiency of a maize-wheat cropping system as affected by different fertilizer management strategies in a farmer's field of the North China Plain. Field Crop. Res. 2015, 174, 30-39. [CrossRef]

16. Yan, X.; Gong, W. The role of chemical and organic fertilizers on yield, yield variability and carbon sequestration-results of a 19-year experiment. Plant Soil 2010, 331, 471-480. [CrossRef]

17. Singh, P.; Singh, D.; Singh, A.K.; Singh, B.K.; Singh, T. Growth and yield of tomato grown under organic and inorganic nutrient management. Int. J. Curr. Microbiol. Appl. Sci. 2020, 9, 365-375. [CrossRef]

18. Du, Y.; Niu, W.; Gu, X.; Zhang, Q.; Cui, B. Water- and nitrogen-saving potentials in tomato production: A meta-analysis. Agric. Water Manag. 2018, 210, 296-303. [CrossRef]

19. Cheng, M.; Wang, H.; Fan, J.; Xiang, Y.; Tang, Z.; Pei, S.; Zeng, H.; Zhang, C.; Dai, Y.; Li, Z.; et al. Effects of nitrogen supply on tomato yield, water use efficiency and fruit quality: A global meta-analysis. Sci. Hortic. 2021, 290, 110553. [CrossRef]

20. Abdalla, M.; Hastings, A.; Cheng, K.; Yue, Q.; Chadwick, D.; Espenberg, M.; Smith, P. A critical review of the impacts of cover crops on nitrogen leaching, net greenhouse gas balance and crop productivity. Glob. Chang. Biol. 2019, 25, 2530-2543. [CrossRef]

21. Niu, J.; Li, Y.; Chen, Q. Solid Organic Waste Fertilizer Utilization Technology; Chemical Industry Press: Beijing, China, 2010.

22. FAO. World reference base for soil resources 2006: A framework for international classification, correlation and communication. World Soil Resour. Rep. 2006, 2, 103.

23. Cai, A.; Chang, N.; Zhang, W.; Liang, G.; Zhang, X.; Hou, E.; Jiang, L.; Chen, X.; Xu, M.; Luo, Y. The spatial patterns of litter turnover time in Chinese terrestrial ecosystems. Eur. J. Soil Sci. 2020, 71, 856-867. [CrossRef]

24. Elith, J.; Leathwick, J.R.; Hastie, T. A working guide to boosted regression trees. J. Anim. Ecol. 2008, 77, 802-813. [CrossRef]

25. Guo, J.H.; Liu, X.J.; Zhang, Y.; Shen, J.L.; Han, W.X.; Zhang, W.F.; Christie, P.; Goulding, K.W.; Vitousek, P.M.; Zhang, F.S. Significant acidification in major Chinese croplands. Science 2010, 327, 1008-1010. [CrossRef] [PubMed]

26. Mahmoud, E.; El-Kader, N.A.; Robin, P.; Akkal-Corfini, N.; El-Rahman, L.A. Effects of different organic and inorganic fertilizers on cucumber yield and some soil properties. World J. Agric. Sci. 2009, 5, 408-414.

27. Qasim, W.; Xia, L.; Lin, S.; Wan, L.; Zhao, Y.; Butterbach-Bahl, K. Global greenhouse vegetable production systems are hotspots of soil $\mathrm{N}_{2} \mathrm{O}$ emissions and nitrogen leaching: A meta-analysis. Environ. Pollut. 2021, 272, 116372. [CrossRef] [PubMed]

28. Ma, Q.; Wen, Y.; Wang, D.; Sun, X.; Hill, P.W.; Macdonald, A.; Chadwick, D.R.; Wu, L.; Jones, D.L. Farmyard manure applications stimulate soil carbon and nitrogen cycling by boosting microbial biomass rather than changing its community composition. Soil Biol. Biochem. 2020, 144, 107760. [CrossRef]

29. Zhang, X.; Fang, Q.; Zhang, T.; Ma, W.; Velthof, G.L.; Hou, Y.; Oenema, O.; Zhang, F. Benefits and trade-offs of replacing synthetic fertilizers by animal manures in crop production in China: A meta-analysis. Glob. Chang. Biol. 2020, 26, 888-900. [CrossRef]

30. Gai, X.; Liu, H.; Liu, J.; Zhai, L.; Yang, B.; Wu, S.; Ren, T.; Lei, Q.; Wang, H. Long-term benefits of combining chemical fertilizer and manure applications on crop yields and soil carbon and nitrogen stocks in North China Plain. Agric. Water Manag. 2018, 208, 384-392. [CrossRef]

31. Zhang, T.; Hou, Y.; Meng, T.; Ma, Y.; Tan, M.; Zhang, F.; Oenema, O. Replacing synthetic fertilizer by manure requires adjusted technology and incentives: A farm survey across China. Resour. Conserv. Recycl. 2021, 168, 105301. [CrossRef]

32. Xia, L.; Shu, K.L.; Ya, X.; Chen, D. How does recycling of livestock manure in agroecosystems affect crop productivity, reactive nitrogen losses, and soil carbon balance? Environ. Sci. Technol. 2017, 51, 7450-7457. [CrossRef]

33. Chatterjee, R.; Bandyopadhyay, S.; Jana, J.C. Impact of organic amendments and inorganic fertilizers on production potential, nitrogen use efficiency and nitrogen balance in tomato (Lycopersicon esculentum Mill.). IJSK 2014, 2, 233-240. [CrossRef]

34. Manna, M.C.; Swarup, A.; Wanjari, R.H.; Mishra, B.; Shahi, D.K. Long-term fertilization, manure and liming effects on soil organic matter and crop yields. Soil Tillage Res. 2007, 94, 397-409. [CrossRef]

35. Mutuku, E.A.; Vanlauwe, B.; Roobroeck, D.; Boeckx, P.; Cornelis, W.M. Physico-chemical soil attributes under conservation agriculture and integrated soil fertility management. Nutr. Cycl. Agroecosyst. 2021, 120, 145-160. [CrossRef]

36. Ding, W.; Lei, H.; Xu, C.; Ke, H.; Li, H. Characteristics and spatial distribution of apparent nitrogen balance in the greenhouse vegetable cropping system in China. J. Agric. Resour. Environ. 2020, 37, 353-360. [CrossRef]

37. Burket, J.; Dick, R. Microbial and soil parameters in relation to $\mathrm{N}$ mineralization in soils of diverse genesis under differing management systems. Biol. Fert. Soils 1998, 27, 430-438. [CrossRef]

38. Zotarelli, L.; Dukes, M.D.; Scholberg, J.; Munoz-Carpena, R.; Icerman, J. Tomato nitrogen accumulation and fertilizer use efficiency on a sandy soil, as affected by nitrogen rate and irrigation scheduling. Agric. Water Manag. 2009, 96, 1247-1258. [CrossRef]

39. Prasad, R.; Shivay, Y.S.; Kumar, D. Current status, challenges, and opportunities in rice production. In Rice Production Worldwide; Springer: Berlin/Heidelberg, Germany, 2017; pp. 1-32.

40. Wang, X.; Xing, Y. Evaluation of the effects of irrigation and fertilization on tomato fruit yield and quality: A principal component analysis. Sci. Rep. 2017, 7, 350. [CrossRef]

41. Gu, J.; Wu, Y.; Tian, Z.; Xu, H. Nitrogen use efficiency, crop water productivity and nitrous oxide emissions from Chinese greenhouse vegetables: A meta-analysis. Sci. Total Environ. 2020, 743, 140696. [CrossRef] 
42. Choudhary, O.P.; Ghuman, B.S.; Dhaliwal, M.S.; Chawla, N. Yield and quality of two tomato (Solanum lycopersicum L.) cultivars as influenced by drip and furrow irrigation using waters having high residual sodium carbonate. Irrig. Sci. 2010, 28, 513-523. [CrossRef]

43. Sánchez-Martín, L.; Arce, A.; Benito, A.; Garcia-Torres, L.; Vallejo, A. Influence of drip and furrow irrigation systems on nitrogen oxide emissions from a horticultural crop. Soil Biol. Biochem. 2008, 40, 1698-1706. [CrossRef]

44. Lv, H.; Lin, S.; Wang, Y.; Lian, X.; Zhao, Y.; Li, Y.; Du, J.; Wang, Z.; Wang, J.; Butterbach-Bahl, K. Drip fertigation significantly reduces nitrogen leaching in solar greenhouse vegetable production system. Environ. Pollut. 2019, 245, 694-701. [CrossRef]

45. Ekenler, M.; Tabatabai, M. Effects of liming and tillage systems on microbial biomass and glycosidases in soils. Biol. Fert. Soils 2003, 39, 51-61. [CrossRef]

46. Zhalnina, K.; Dias, R.; de Quadros, P.D.; Davis-Richardson, A.; Triplett, E.W. Soil pH determines microbial diversity and composition in the park grass experiment. Microb. Ecol. 2015, 69, 395-406. [CrossRef]

47. Van Veen, J.; Kuikman, P. Soil structural aspects of decomposition of organic matter by micro-organisms. Biogeochemistry 1990, 11, 213-233. [CrossRef]

48. Ke, J.; Xing, X.; Li, G.; Ding, Y.; Dou, F.; Wang, S.; Liu, Z.; Tang, S.; Ding, C.; Chen, L. Effects of different controlled-release nitrogen fertilisers on ammonia volatilisation, nitrogen use efficiency and yield of blanket-seedling machine-transplanted rice. Field Crops Res. 2017, 205, 147-156. [CrossRef] 